\title{
Fear Abounds In The Educational Environment: Teachers' Professional Competencies In The Management Of Knowledge
}

Prakash Singh, Nelson Mandela Metropolitan University, South Africa

\begin{abstract}
The introduction of the outcomes-based education (OBE) approach in South African schools over a decade ago led to a discrepancy between the teachers' knowledge of the traditional curriculum and the curriculum based on OBE principles. Adoption of the OBE approach was not an easy passage for most teachers to manage knowledge in education in South Africa. Lack of resources and inadequate professional development and training were - and still are - one of the major challenges facing teachers in transforming the educational system. Not having the capacity to usher in the changes at the classroom level has led to untold levels of anxiety, stress and tension within the teaching community. These developments contributed to the existence of a phobia in the educational environment; namely, Tobephobia (TBP). In this paper, TBP alludes to the fear of failure experienced by teachers to achieve planned educational outcomes. Therefore, this exploratory research examined the question, "What is the impact of TBP and OBE on teachers?" A survey was conducted amongst 311 teachers in Port Elizabeth and Durban, South Africa. The results confirm the very negative impact of TBP and OBE on teachers. Associated with this finding are the high levels of anxiety, stress, and the fear of the outcomes in education experienced by these teachers. In dealing with TBP, it is of vital importance that teachers become aware of their fears, identify their ways in which they express fear, recognise the situations that trigger fear and use appropriate strategies to reduce fear and stress in their lives.
\end{abstract}

Keywords: Knowledge Management; Teachers' Fears; Tobephobia; Outcomes-Based Education

\section{INTRODUCTION}

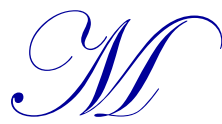

otivational research on achievement situations avers that while some individuals have an achievement orientation, others can be imbued with a fear of failure orientation (Martin \& Marsh, 2003; Gastorf \& Teevan, 1980; McClelland, Atkinson, Clark \& Lowell, 1953; Birney, Burdick \& Teevan, 1969; Singh, 2011). Studies over the past six decades indicate that fear of failure is a multifaceted form of avoidance motivation that can be linked to an acute emotional sensitivity when individuals fail to meet expectations (Atkinson, 1957; McGregor \& Elliot, 2005; Wright, Pincus, Conroy \& Elliot, 2009). This failure-avoidant motive could result from a fear of change within one's environment (Gastorf \& Teevan, 1980; Schargel, 2010; Schargel, 2011). Fear of failure is a persistent and irrational anxiety about failing to measure up to the standards and goals set by oneself or others (Elliot \& Thrash, 2004; VandenBos, 2007; Martin \& Marsh, 2003). This may include anxiety over academic standing or the loss of face and self-esteem. Fear of failure can be defined as a disposition to "avoid failure in achievement settings because one feels shame on failure" (Elliot \& Thrash, 2004: 958).

Prompted by the pioneering research of Atkinson (1957, 1964), researchers have studied the flip-side of achievement motivation; namely, the fear of failure in education (Spitzer, 1977). Birney, Burdick and Teevan's (1969) theory on the fear of failure indicates that individuals attempt to escape from achievement-oriented situations because of their fear of failure in those situations. For teachers, the fear is also associated with curriculum mandates 
(Ginsberg \& Cooper, 2008). For many teachers who cannot cope with sudden changes in the curriculum, fear of failure is clearly a foe yielding high anxiety and reduced resilience (Martin \& Marsh, 2003).

Over the past decade, major changes have taken place in the South African educational knowledge system as it epitomizes the growing and changing educational needs of a developing country. The introduction of the outcomes-based education (OBE) approach in South African schools over a decade ago led to a discrepancy between the teachers' knowledge of the traditional curriculum and the curriculum based on OBE principles. Adoption of the OBE approach was not an easy passage for most teachers to manage knowledge in education in South Africa. Lack of resources and inadequate professional development and training were - and still are - one of the major challenges facing teachers in transforming the educational system. Not having the capacity to usher in the changes at the classroom level has led to untold levels of anxiety, stress, and tension within the teaching community (Kyriacou, 1998; Singh, 2008; Singh, 2011). These developments contributed to the existence of a phobia in the educational environment; namely, Tobephobia (TBP) (Singh, 2006; Singh, 2007; Singh, 2008; Lunn, 2009; Wildemann, 2009; Singh \& Morar, 2009; Ramkhelawon, 2010; Singh, 2011). TBP is a fear of being incompetent to carry out one's professional teaching obligations in a disabling educational environment (Singh, 2008; Futernick, 2010; Singh, 2010; Singh, 2011; Schargel, 2011).

Over the past two decades, research on the phenomenon of TBP alludes to the fear of the outcomes in education (Singh \& Manser, 2000; Mofokeng, 2004; Lunn, 2009; Singh, 2011; Wildemann, 2009). According to Wildemann (2009), "there are many educators worldwide that are affected by the changes that take place in the education environment; therefore, if made aware of this new term, many would concur that they are suffering from Tobephobia" (p.9). Tobephobic people in education spend most of their time worrying about their fears of failure to achieve the prescribed educational outcomes and tend to be too frightened to attend to their normal daily chores (Martin \& Marsh, 2003; Gardner \& Bell, 2005; Lunn, 2009; Singh, Manser, \& Dali, 2013). According to Pfeffer and Sutton (2000), in organisations that fail to translate knowledge into action, the prevailing atmosphere will be that of fear and distrust. Hargreaves, as quoted by Fullan (2006), contends that:

Government must give active permission to schools to innovate and provide a climate in which failure can be given a different meaning as a necessary element in making progress, as is the case in the business world...mistakes can be accepted or even encouraged, provided that they are a means of improvement. (p.119)

Multiple studies (Singh, 2008; Singh \& Morar, 2009; Lunn, 2009; Wildemann, 2009; Ramkhelawon, 2010; Singh, 2010; Singh, 2011; Singh, Manser \& Dali, 2013) on the construct TBP simply define it as the fear of failure in education. Being unable to achieve planned educational outcomes is experienced not only by teachers, but also by other key stakeholders in education. However, in this article, the focus is on teachers' experiences of fear of failure caused by curriculum change such as OBE in South Africa. It is far from clear what it would mean to implement a curriculum for teachers who were not trained in the curriculum as this would inevitably result in significant decreases in learner performance (Schoenfeld, 2006; Futernick, 2010). Therefore, the statement of the problem for this study is, "What is the impact of TBP and OBE on teachers?"

\section{Fear Abounds In The Educational Environment}

\section{Teacher Training To Manage Curriculum Change}

Curriculum implementation failure is a common problem experienced by teachers when they lack the knowledge and skills to teach the subject matter. Policy statements do not easily feed into the practice of teaching. Teachers will feel threatened by the prospect of change in the curriculum if they are inadequately prepared for it (Zimmerman, 2006; Lunn, 2009; Wildemann, 2009; Singh, 2011). Their acceptance of curriculum change could be affected by perceived threats to their expertise and proven abilities and their belief that they lack the professional competence to implement curriculum change successfully (Greenberg \& Baron, 2000; Fullan, 2001). As pointed out by Zimmerman (2006), "teachers and others who benefit from the current distribution and control of resources might perceive threats to their resource allocations brought about by changes in the school" (p.240). Kealey, Peterson, Gaul and Dinh (2000) also observed that teacher training conceptualized as a positive behaviour change process can promote effective implementation of curriculum change in school classrooms if it leads to the upgrading of teachers' knowledge and skills. 
It is axiomatic that school-based curricula are provided to learners by their teachers, making teachers key to the effective implementation of the curriculum (Futernick, 2010; Schargel, 2010; Singh, 2011). Therefore, as pointed out by Kealey et al. (2000), teacher training is regarded as being essential for the effective implementation in schools of any innovative curriculum. Several studies have confirmed that when teacher training is overlooked or is ineffective, this would result in the implementation failure of the curriculum (Kealey et al., 2000; Schoenfeld, 2006; Futernick, 2010; Schargel, 2010; Singh, 2011). According to Ginsberg and Lyche (2008), it seems clear that "rising interest and negative feelings have taken hold and that a culture of fear has emerged concerning issues of public education" (p.26). This can be attributed to teachers' incompetence to usher in curriculum change, such as the OBE curriculum, as a result of inadequate or no professional development of their knowledge and skills. Consequently, their fear of failure; that is TBP, will make it simply easier for them to continue teaching in the same old traditional ways, thus maintaining the status quo (Greenberg \& Baron, 2000; Lunn, 2009; Futernick, 2010; Schargel, 2010; Singh, 2011).

The abrupt introduction of the OBE curriculum in South Africa created resentment, anxiety and fear amongst teachers (Taylor \& Vinjevold, 1999; Mofokeng, 2004, Chisholm, 2000; Singh, 2008). In a study on TBP by Wildemann (2009), she found that many teachers were highly frustrated at the disorganized structure that OBE had caused:

Nothing seems to be of a definite structure e.g. unable to predict definite content to an exam on both teacher and pupils' side. Everything is so vague. Group work allows the weaker pupils to do nothing and get away with it (p.16).

One of the major flaws in the implementation of OBE in South Africa was the lack of adequate training of teachers. Teachers had no clarity of what was required of them (Masondo, Mahlangu \& Mclea, 2010). Even in the Report of the Task Team (DoE, 2009) which reviewed the implementation of the National Curriculum Statement, it was unanimously stated that "current teacher policies to support the curriculum are often too generic and superficial and did not provide the needed support to teachers" (p.10). Research shows that there is a lack of a clearly articulated educational justification for OBE or even plausible evidence to prove its success (DoE, 2009; Donnelly, 2007; Alderson \& Martin, 2007; Berlach \& Mcnaught, 2007; Donnelly, 2005).

An analysis of the obstacles of getting teachers involved in curriculum change is evident when viewed in terms of their perspective (Ornstein \& Hunkins, 2004; Balt, 2008; Futernick, 2010; Schargel, 2010; Singh, 2011):

1. Lack of Ownership: Much of the current demand to implement the National Curriculum Statement to transform the curriculum stems from the national government in South Africa; hence, teachers are not readily accepting this top-down bureaucratic approach from an external source.

2. Differential Knowledge: Teachers tend to feel frustrated that their power base has been increasingly eroded by those external forces imposing change in the school without concomitantly putting into place supporting infrastructure.

3. Sudden Wholesale Change: Curriculum change was introduced in South Africa without concomitantly upgrading the knowledge and skills of teachers to teach the new curriculum. Most of these teachers suffer from acute bouts of fear of failure; that is TBP, because of a lack of proper training.

It is important to identify the symptoms of teachers' fear of failure associated with curriculum change so that measures can be put into effect by education authorities to remedy it. Some symptoms of fear of failure displayed by teachers are (MindTools, 2013):

1. Reluctance to try new curriculum approaches in the classroom, e.g. self-regulated learning. Teacher training largely focuses on cognition. What about metacognition and emotional intelligence? To what extent are innovative approaches in education compatible with teachers' professional competencies? Such questions need to be seriously and continuously addressed by the State responsible for the employment of teachers.

2. Self-sabotage: For example, procrastination of teaching something that they are not trained in, excessive anxiety, or a failure to follow through the entire process to achieve the educational outcomes. 
3. Low Self-esteem or Self-confidence: Commonly using negative statements such as "I'm not competent enough to teach the new contents." The question arises whether there are adequate measures in schools, such as a peer mentoring system and counselling, that could raise the self-esteem and, consequently, the emotional intelligence of educators.

4. Perfectionism: A willingness to try only those things that they will be able to finish perfectly and successfully within a pre-determined comfort zone.

Lunn's (2009) study on TBP created an increase in the awareness of TBP among the teachers she interacted with. The teachers, in her study, indicated that anxiety, stress, demotivation, depression, hopelessness, and pessimism were experienced as major symptoms of TBP. She confirms that the research has made it more apparent that TBP is indeed a reality in our schools. She asserts that ignoring it will not be conducive to a healthy working environment in our schools.

The professional incompetence of teachers to successfully implement the planned curriculum in their classrooms has a negative bearing on learning outcomes (Menuey, 2005). Research shows that learners taught by incompetent teachers experience cognitive dissonance, resulting in lasting decreased achievement (Dawson \& Billingsley, 2000; Sanders \& Horn, 1998; Jones, 1997; Tucker, 1997; Neill \& Custis, 1978). There is ample evidence that poor teaching materially contributes to higher levels of failure rates amongst learners (Fuhr, 1993).

Teacher quality is severely compromised in many schools when teachers are assigned to courses in which they have little subject matter knowledge. These "mis-assignments" occur when district administrators do not have enough teachers qualified to teach a subject - like mathematics, science, or English - and they are forced to assign under-qualified teachers (Futernick, 2010). Lack of manageable workloads, the expansion of the curriculum, and a lack of continuous skill development have been cited by Conley and Glasman (2008) as sources of fear experienced by teachers. Eisner (1995) argues that it is difficult to be pedagogically graceful when you are lost in unfamiliar territory. Under these circumstances, teachers are often reluctant to relinquish traditional teaching repertoires that serve as a source of security for them (Singh, 2011).

\section{Tobephobia And Teachers' Fear Of Failure}

Fear of failure is a persistent and irrational anxiety about failing to measure up to the standards and goals set by oneself or others (Elliot \& Thrash, 2004; VandenBos, 2007; Martin \& Marsh, 2003). This may include anxiety over academic standing or the loss of face and self-esteem. Fear of failure can be defined as a disposition to "avoid failure in achievement settings because one feels shame on failure" (Elliot \& Thrash, 2004: 958). Stress, pressure and fear at work can cause tension, poor focus, fatigue, and distress amongst teachers (Clarkson, 2004).

Absenteeism increases as weakened immune systems become more susceptible to illness. Increased stress levels can be contributed to teachers being asked to do more with fewer resources, teachers feeling powerless and uncertain about their jobs, and teachers' reactions to bureaucracy and staffroom politics. When combined, these form cumulated distress which is not a recipe for success in the classroom, but rather a disaster. The effects of TBP directly impact negatively on how the teacher will teach and how the learner will learn (Singh, 2008; Singh, 2011).

In a study on TBP by Singh and Morar (2009), a teacher confessed that:

Although Tobephobia is not a well-known concept, it is one that has a great effect on all of us. Tobephobia is a concept that can and will have a great effect on our learners who are the future of our nation. Tobephobia is an emotional state which the teacher develops. This fear has a great impact on the way the educator performs and behaves in the classroom. The educator wants to educate his or her learners, but to experience fear is clearly the last thing an educator wants to happen in the classroom. Nobody seems to appreciate a teacher anymore. Learners and parents do not respect teachers. This has a negative impact on the morale of educators (p.98).

In the same study (Singh \& Morar, 2009), another teacher described his experiences of TBP as follows: 
Teaching was my first and only job that I ever had. I entered this profession with equal measure of bumptious pride and genuine determination to make a positive impact on young lives. Nineteen years later, all vestiges of my initial optimism had rotted into laughable, bitter memories. At times, I feel buried alive in an avalanche of spit balls and unremitted hostility from learners, their parents, and the Department of Education. As it was, I had no inkling that there was a psychological term for what I was experiencing: Tobephobia! (p.94)

Spitzer (1977) asserts that the need for achievement and the fear of failure have been shown to be orthogonal to each other. Spitzer's (1977) study found that the following characteristics lead to high levels of fear of failure and insecurity amongst teachers:

1. Lack of teacher effectiveness

2. Teachers being subjected to continual criticism with little praise

3. Lack of validated competencies

4. Lack of collegial co-operation

When widely publicized questions emerge about a failing educational system, then uncertainty and fear are inevitable outcomes (Ginsberg \& Lyche, 2008; Grant, 2009). Several studies (Martin \& Marsh, 2003; Gardner \& Bell, 2005; Singh, 2011; Lunn, 2009; Wildemann, 2009; Singh \& Morar, 2009) strongly suggest that fear of failure can drain teachers of their motivation and inspiration and it prevents them from realising their full potential as it impacts negatively on them personally, their teaching, on learners, and on the teaching profession. TBP is a major phenomenon that cannot be simply wished away.

In his study on the rate of teacher attrition, Futernick (2007) identified key challenges faced by teachers:

1. A greater number of children are coming to school without family support.

2. Teachers are required to do and achieve more in a limited period of time.

3. Teachers are expected to be experts in all fields.

4. There is too little planning time and too much paperwork.

5. There is lack of administrative support and unreliable assistance from the district officials.

6. Undue pressure from parents and learners requires more time and attention.

As pointed out by Futernick (2007), the "most basic findings from our study tell us that teachers are less concerned with compensation (though they are not unconcerned with it) than they are with a whole range of particulars about their work environment. Work environment, or perhaps more specifically described as the teaching and learning environment, refers not just to leaks in the ceilings or toilets that do not flush, though poorly maintained classrooms and school facilities are as dispiriting to teachers as they are to students." He also affirms that the teaching and learning environment refers to a whole range of instructional, collegial, and systemic conditions which, for many, make teaching a highly satisfying profession. It is a profession that reminds those who have chosen it that they are making a positive impact on students and society. A central finding in Futernick's study found that many teachers leave schools long before retirement because of inadequate system supports, such as too little time for planning, too few textbooks, and unreliable assistance from the district office.

In one of the studies focusing on teachers' fear of failure, a teacher candidly conceded that (Singh, 2011):

The word Tobephobia though will surely be regarded as a blessing by many teachers because finally, there is a word that will make people sit up and listen to issues that cause real fear and anxiety in teachers because of the constant changes being made in the education system (p.380).

In another study on TBP, a stressed teacher explained her inability to manage TBP as follows (Ramkhelawon, 2010):

As an educator in this ruthless system, I had to succumb to the unfair and unrealistic demands that are imposed on me, thus creating feelings of anxiety, fear, stress, tension, anger, unhappiness, disappointment, and uncertainty. The thoughtless changes ushered in by the education authorities create a void in the teaching fraternity, as well as in the lives of the future generation - our learners (p.2). 
Evidently, fear abounds in the educational environment when teachers fail to teach their learners what is expected of them (Ginsberg \& Cooper, 2008). Newkirk (2009) asserts that for teachers, their professional identity "is bound up in their teaching success; when they fail, something very precious can be put at risk" (p.164). He notes that difficulty, disappointment, resistance, and failures are inevitable in the profession of teaching. Definitely, some failure is a natural consequence of the tremendous challenges teachers take on in their schools (Tedrow, 2010). Lack of manageable workloads, the expansion of the curriculum, and a lack of continuous skill development have been cited by Conley and Glasman (2008) as sources of fear experienced by teachers. When questions are raised about the relevance of the curriculum and the ability of teachers to teach it, then fear of failure will be associated with the teachers' inability to teach it (Futernick, 2010; Schargel, 2010; Singh, 2011).

\section{EMPIRICAL STUDY}

The aim of this study was to undertake an exploratory study of whether fear abounds in the educational environment. The objective of this study was to investigate the impact of OBE and TBP on teachers. A multirespondent survey design was used to conduct the investigation. In such a design, the focus is on relationships between and among variables in a single group (Robson, 2002). The subjects chosen to participate in the study were selected following a process described by McMillan and Schumacher (2001:175) as non-probability convenience sampling because the subjects were selected on the basis of their accessibility and availability. Hence, for the purpose of this study, the participants were teachers studying at the Nelson Mandela Metropolitan University (NMMU). Ethics clearance to proceed with the study was granted by the institution (NMMU).

The questionnaires were completed by teachers from Port Elizabeth and Durban, South Africa (see Table 1). Seeing that the main NMMU campus is based in Port Elizabeth, $78.8 \%$ of the respondents were from this site. For ethical reasons, respondents were advised not to disclose their names and the names of their schools on the questionnaire. Confidentiality and anonymity were thus ensured and the participation of the respondents was on a totally voluntary basis. Of the 335 questionnaires distributed, 311 completed questionnaires were returned. This represented a return rate of $92.8 \%$.

The structured questionnaire was initially compiled by the author of this study. An extensive literature review on achievement motivation and the fear of failure experienced by teachers was consulted in the first stage of developing the questionnaire. This first draft copy was then subjected to further review and modification by a qualified statistician at NMMU. Thereafter, the second draft copy of the questionnaire was critically reviewed by four teachers, two principals, an academic with curriculum specialization, and an educational psychologist. Their critical input was duly considered in finalizing the questionnaire for this study. This process ensured the face validity and the content validity of the measuring instrument used for the research.

The questionnaire was divided into two sections:

1. Section A - The demographic variables of the participant

2. Section B - A Tobephobia inventory

However, in terms of the delimitation and focus of this article, the two sub-sections in the questionnaire that will be addressed in this article are:

1. Sub-section 6 - Perceptions of the negative impact of TBP on teachers' job satisfaction

2. Sub-section 10 - To what extent does OBE impact on current teaching?

In sub-section 6, respondents were required to respond to six questions with three options - agree fully (A+), agree partially (A-), or disagree (D). In sub-section 10, the respondents also had to consider a level of perceived impact with options - major $(\mathrm{M}+)$, minor $(\mathrm{M}-)$, or none $(\mathrm{N})$. Summated scores were calculated for each of the sub-sections in section $\mathrm{B}$ of the questionnaire by mapping the average of the relevant items ranging from 1 $(\mathrm{A}+\mathrm{M}+)$ to $3(\mathrm{D} / \mathrm{N})$ to a score between 0 (very low negative impact) and 100 (very high negative impact). Cronbach's alpha coefficient values were used to determine the reliability (internal consistency) of the summated scores. 


\section{DATA ANALYSIS}

The data analysis was conducted by a qualified statistician at NMMU. Descriptive statistics were used to summarise the sample statistics while inferential tests were conducted to investigate the significance of relationships among variables. Inferential test results were deemed significant if they were both statistically significant at the $\alpha=$ .05 level and also practically significant according to the guidelines for the relevant test.

The characteristics of the respondents are summarised in Table 1. It clearly reflects the representativeness of the sample for this study.

Table 1: Respondents' Characteristics $(n=311)$

\begin{tabular}{|c|c|c|c|c|c|}
\hline Site & $\%$ & n & Gender & $\%$ & $\mathbf{n}$ \\
\hline Port Elizabeth & 78.8 & 245 & Male & 35.7 & 111 \\
\hline Durban & 21.2 & 66 & Female & 64.3 & 200 \\
\hline \multicolumn{3}{|l|}{ Post Level } & \multicolumn{3}{|l|}{ Grades and Phases } \\
\hline Teacher & 69.5 & 216 & $1-3$ & 4.2 & 13 \\
\hline Head of Dept & 14.5 & 45 & $4-6$ & 9.9 & 31 \\
\hline Deputy Principal & 10.8 & 34 & $7-9$ & 36.3 & 113 \\
\hline Principal & 3.2 & 10 & $10-12$ & 48.6 & 151 \\
\hline Other & 2 & 6 & Other & 1.0 & 3 \\
\hline \multicolumn{3}{|l|}{ Home Language } & \multicolumn{3}{|l|}{ Highest Qualification } \\
\hline English & 45.7 & 142 & Grade 12 or lower & 0 & 0 \\
\hline Afrikaans & 18.0 & 56 & Teaching Diploma & 16.4 & 51 \\
\hline Xhosa & 29.9 & 93 & Degree & 28.3 & 88 \\
\hline Zulu & 6.1 & 19 & Degree + Teaching Diploma & 32.8 & 102 \\
\hline \multirow{2}{*}{\multicolumn{3}{|c|}{ Other }} & Post Graduate Degree & 5.4 & 17 \\
\hline & & & Post Grad. Degree + Teaching Diploma & 17.1 & 53 \\
\hline \multicolumn{3}{|l|}{ Age } & \multicolumn{3}{|l|}{ Years Teaching Experience } \\
\hline $20-29$ & 13.5 & 42 & $0-2$ & 8.4 & 26 \\
\hline $30-39$ & 18.0 & 56 & $3-4$ & 4.8 & 15 \\
\hline $40-49$ & 44.7 & 139 & $5-9$ & 10.0 & 31 \\
\hline $50-59$ & 22.2 & 69 & $10-19$ & 38.3 & 119 \\
\hline $60+$ & 1.6 & 5 & $20+$ & 38.5 & 120 \\
\hline \multicolumn{6}{|l|}{ School Type } \\
\hline \multicolumn{4}{|c|}{ Ex-Model C School } & 19.6 & 61 \\
\hline \multicolumn{4}{|c|}{ Section 21 Urban State School } & 45.3 & 141 \\
\hline \multicolumn{4}{|c|}{ Section 21 Rural State School } & 4.8 & 15 \\
\hline \multicolumn{4}{|c|}{ Independent School } & 12.2 & 38 \\
\hline \multicolumn{4}{|c|}{ Non-section 21 Urban State School } & 12.2 & 38 \\
\hline \multicolumn{4}{|c|}{ Non-section 21 Rural State School } & 3.2 & 10 \\
\hline \multicolumn{4}{|l|}{ Farm School } & 2.7 & 8 \\
\hline
\end{tabular}

The responses to the items relating to the impact of TBP and OBE on teaching are summarised in Tables 2 and 3.

Table 2: Frequency Distribution: Sub-Section 6 Items Relating To Impact Of TBP On Teachers' Job Satisfaction (n=311)

TBP has a negative impact on the self-esteem of teachers.

Teachers are demotivated as a result of TBP.

Teachers develop a negative attitude towards their job because of TBP.

TBP results in teachers disliking their job.

TBP leads to pessimism experienced by teachers.

Teachers have low expectations as a result of TBP.

\begin{tabular}{|c|c|}
\hline Agree Fully & Agree Partially \\
$77 \%$ & $21 \%$ \\
$76 \%$ & $23 \%$ \\
$75 \%$ & $23 \%$ \\
$72 \%$ & $26 \%$ \\
$70 \%$ & $27 \%$ \\
$68 \%$ & $29 \%$ \\
\hline
\end{tabular}

Disagree

$2 \%$

$1 \%$

$2 \%$

$2 \%$

$3 \%$

$3 \%$ 
From Table 2, it is clear that the majority of the respondents were fully in agreement regarding the negative impact of TBP on teachers' job satisfaction, ranging between approximately 2 out of 3 (68\%) to 3 out of 4 (77\%) for the six items.

Table 3: Impact Of OBE On Teaching

Increase in administrative tasks erodes the quality teaching time of teachers.

Teachers are not professionally trained to teach the new curriculum.

OBE is all about the stakeholders and not the teachers.

Anyone and everyone are expected to teach anything at any time.

Teachers are stripped of their traditional role to impart knowledge.

Teachers' positions have been downgraded to being facilitators.

Teachers have lost their authority in the classrooms.

\begin{tabular}{|c|c|c|}
\hline Major & Minor & None \\
\hline $85 \%$ & $13 \%$ & $2 \%$ \\
$71 \%$ & $23 \%$ & $6 \%$ \\
$58 \%$ & $33 \%$ & $9 \%$ \\
$55 \%$ & $24 \%$ & $21 \%$ \\
$51 \%$ & $33 \%$ & $16 \%$ \\
$49 \%$ & $40 \%$ & $11 \%$ \\
$47 \%$ & $40 \%$ & $13 \%$ \\
\hline
\end{tabular}

The results in Table 3 indicate greater variability with regard to the impact of OBE on teaching compared to that for the impact of TBP on teachers' job satisfaction. The largest proportion of the sample perceived OBE as having a major negative impact on teaching, ranging between almost half $(47 \%)$ to $85 \%$ of the respondents for the seven items.

The observed Cronbach's coefficient alpha values of 0.91 and 0.87 , respectively, for the summated scores measuring the negative impact of TBP and OBE on teachers were much higher than 0.70 , the minimum value being regarded as significant, thus confirming the scores' reliability.

Descriptive statistics for the summated scores measuring the negative impact of TBP and OBE on teachers are reflected in Table 4. High mean scores of 85.23 and 74.22 were observed for TBP and OBE factors, respectively, on a scale ranging from 0 (very low negative impact) to 100 (very high negative impact). Approximately half (51\%) of the respondents obtained TBP scores ranging from 90 to 100, whilst just more than half (54\%) obtained OBE scores of 75 or higher.

Table 4: Descriptive Statistics Of The Scores Measuring The Negative Impact Of TBP And OBE On Teachers $(n=311)$

\begin{tabular}{|c|c|c|c|c|}
\hline \multirow{2}{*}{$\begin{array}{l}\text { Score } \\
\text { Interval }\end{array}$} & \multicolumn{2}{|c|}{ TBP } & \multicolumn{2}{|c|}{ OBE } \\
\hline & Percentage & Cumulative & Percentage & Cumulative \\
\hline \multirow{6}{*}{$\begin{array}{l}{[90-100]} \\
{[75-89]} \\
{[50-74]} \\
{[25-49]} \\
{[10-24]} \\
{[0-9]}\end{array}$} & $51 \%$ & $51 \%$ & $32 \%$ & $32 \%$ \\
\hline & $28 \%$ & $79 \%$ & $23 \%$ & $54 \%$ \\
\hline & $19 \%$ & $98 \%$ & $33 \%$ & $87 \%$ \\
\hline & $2 \%$ & $100 \%$ & $11 \%$ & $98 \%$ \\
\hline & $0 \%$ & $100 \%$ & $1 \%$ & $99 \%$ \\
\hline & $0 \%$ & $100 \%$ & $1 \%$ & $100 \%$ \\
\hline \multicolumn{5}{|l|}{ Statistic } \\
\hline Mean & \multicolumn{2}{|c|}{85.23} & \multicolumn{2}{|c|}{74.22} \\
\hline Std. Dev. & \multicolumn{2}{|c|}{15.72} & \multicolumn{2}{|c|}{22.44} \\
\hline Minimum & \multicolumn{2}{|c|}{29.00} & \multicolumn{2}{|c|}{0.00} \\
\hline Quartile 1 & \multicolumn{2}{|c|}{75.00} & \multicolumn{2}{|c|}{57.00} \\
\hline Median & \multicolumn{2}{|c|}{92.00} & \multicolumn{2}{|c|}{79.00} \\
\hline Quartile 3 & \multicolumn{2}{|c|}{100.00} & \multicolumn{2}{|c|}{93.00} \\
\hline Maximum & \multicolumn{2}{|c|}{100.00} & \multicolumn{2}{|c|}{100.00} \\
\hline
\end{tabular}

Figure 1 is a frequency scatterplot depicting the relationship between the negative impact of OBE and that of TBP. The observed Pearson Product Moment correlation value was .405 which was found to be significant ( $\mathrm{r}>$ $.111, \alpha=.05$ level threshold value level, and also $r>.300$ the threshold value for moderate practical significance).

To further investigate the relationship between the impact of OBE and that of TBP on teachers, a Chi ${ }^{2}$ test of independence was conducted based on the contingency table reflected in Table 5. 


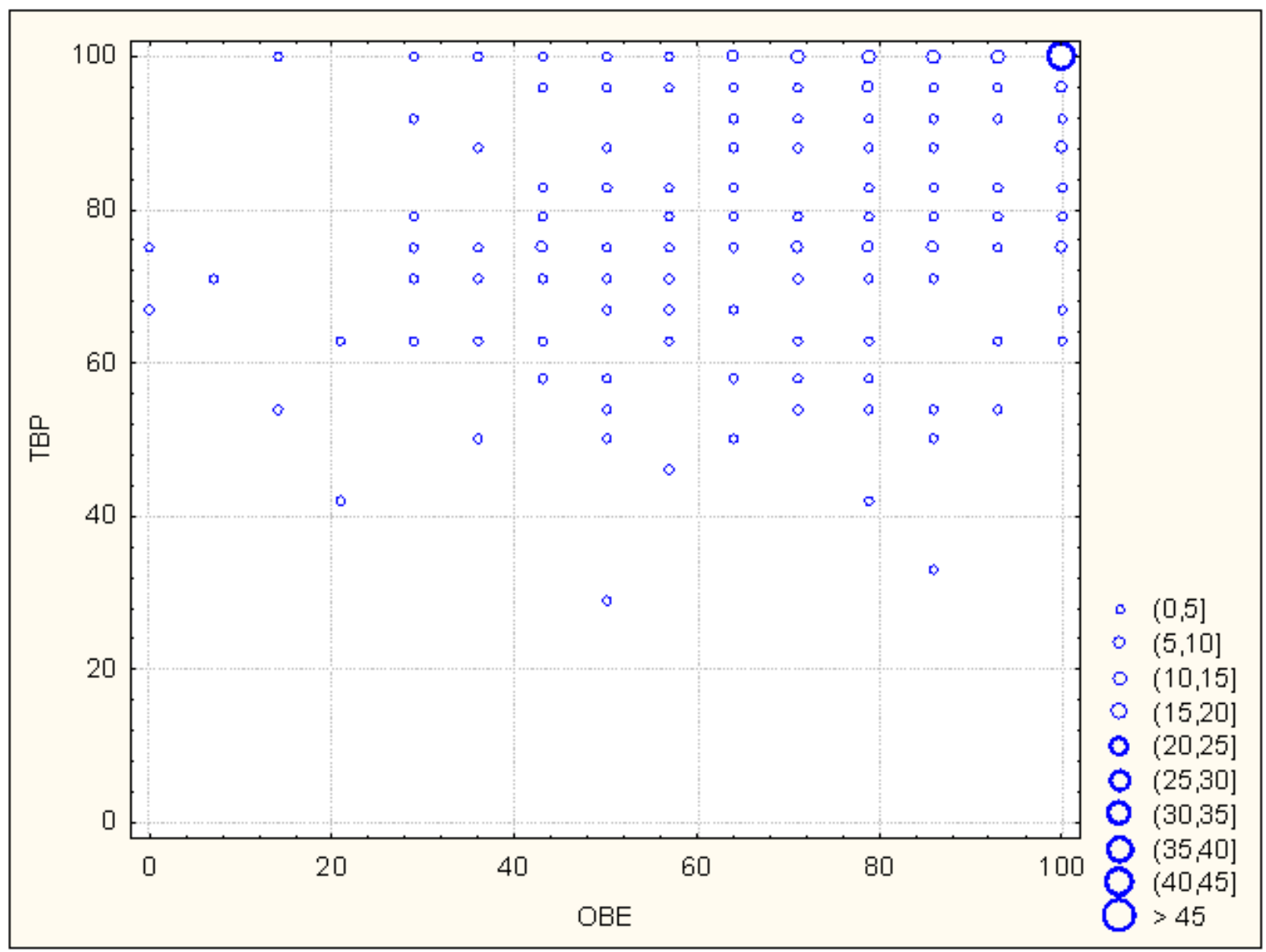

Figure 1: The Relationship Between The Negative Impact Of OBE On Teachers With That Of TBP

Table 5: Contingency Table Depicting The Relationship Between

The Negative Impact Of OBE On Teachers And That Of TBP On Teachers' Job Satisfaction

\begin{tabular}{|c|c|c|c|c|c|c|c|}
\hline \multirow[b]{2}{*}{ OBE } & \multicolumn{7}{|c|}{ TBP } \\
\hline & \multicolumn{2}{|c|}{ Below Average } & \multicolumn{2}{|c|}{ Average } & \multicolumn{2}{|c|}{ Above Average } & Total \\
\hline Below Average & 26 & $43 \%$ & 22 & $36 \%$ & 13 & $21 \%$ & 61 \\
\hline Average & 35 & $20 \%$ & 67 & $38 \%$ & 76 & $43 \%$ & 178 \\
\hline Above Average & 3 & $4 \%$ & 20 & $28 \%$ & 49 & $68 \%$ & 72 \\
\hline Total & 64 & $21 \%$ & 109 & $35 \%$ & 138 & $44 \%$ & 311 \\
\hline
\end{tabular}

Given the observed significant positive correlation coefficients and the significant outcome of the Chi ${ }^{2}$ test of independence, it can be concluded that in South African schools where the negative impact of OBE on teachers is high, it will typically be found that the negative impact of TBP on teachers' job satisfaction is also high.

\section{DISCUSSION}

Only $2 \%$ of the teachers disagreed that TBP had a negative impact on their self-esteem as teachers. Ninetynine percent of these teachers indicated that they suffered from demotivation as a result of TBP. Seventy-six percent of them agreed fully with this statement. Ninety-eight percent of the teachers either agreed fully (75\%) or agreed partially $(23 \%)$ that they developed a negative attitude toward their job because of TBP and hence, only $2 \%$ and $3 \%$ indicated that TBP had no impact on liking their jobs or being optimistic about their job satisfaction, respectively. The findings also confirmed that $97 \%$ of the teachers have low expectations regarding job satisfaction. 
Regarding the impact of OBE on teaching, 98\% of the teachers believed that administrative tasks eroded their quality teaching time. Ninety-four percent of them believed that they were not professionally competent to teach the OBE curriculum. More than fifty percent of these teachers indicated that being asked to teach anything without having the basic training in the subject area had a detrimental impact on their ability to impart knowledge to their learners. Only $13 \%$ of the teachers felt that they retained their traditional authority in the classroom. The findings suggest that a total of $89 \%$ of the teachers believed that OBE had either a major $(49 \%)$ or minor $(40 \%)$ impact on their traditional positions as teachers, indicating that their roles have been downgraded to that of being mere facilitators in the instructional process.

In driving out fear during hard times, Pfeffer and Sutton (2000) provide the following guidelines for action:

1. Prediction: Give employees as much information as possible about what will happen to them and when it will happen.

2. Understanding: Give employees detailed information about why actions, especially actions that upset and harm them, were taken.

3. Control: Give employees as much influence as possible over what happens, when things happen, and the way things happen to them; let them make as many decisions about their own fate as possible.

4. Compassion: Convey sympathy and concern for the disruption, emotional distress, and financial burdens that people face.

Organisations, such as schools, should be in a better position to turn knowledge into action in order to drive out fear. Admittedly, there is no doing without mistakes, especially when constant changes are being made and teachers need to simultaneously develop their competencies to successfully engage in the management of knowledge.

One of Deming's (1986) prescriptions for organisational success is to drive out fear and create trust. Teachers need to know that there can be ways to reduce their fear of failure as suggested below (MindTools, 2013):

1. Analyse All Potential Educational Outcomes: Many teachers experience TBP because they fear that they will make incorrect decisions about curriculum implementation and evaluation, as is evident in this study. In order to address this concern, they must consider all potential outcomes of their decisions. Use of Decision Trees, for example, can create opportunities based on their expectations when they creatively map possible educational outcomes visually.

2. Learn To Think More Positively: Positive thinking and shared decision-making are an incredible, powerful, collegial way to build self-confidence and neutralize self-sabotage in the educational environment.

3. Consider How Bad Is The Worse-Case Scenario: The worse-case may actually not be that bad when all the options are considered by teachers who often feel that their competencies are inadequate to cope with the fluid situation in their schools. Self-regulated learning can be an indispensable tool to develop their capacity (Singh, 2013).

4. Have A Contingency Plan: Teachers need to have a "Plan B" in place so that they can feel more confident about moving forward. Mentoring and being part of professional learning communities can be of great help to offset their fear of failure when faced with the challenges of implementing a new curriculum.

To improve the service conditions of teachers, the following recommendations can reduce teachers' fear of failure (Schargel, 2011; Futernick, 2007):

1. School administrators should continually assess teaching conditions.

2. Education funding should be increased to at least adequate levels.

3. The State should introduce administrative policies that support teachers' instructional needs.

4. Principals should focus on high quality teaching and learning conditions.

5. The State should establish standards for teaching and learning conditions.

6. Administrators should address specific challenges in retaining special education teachers. 
In addition to meaningful performance evaluation of teachers that is tied to high-quality professional development, peer mentoring, and classroom assignments that effectively match their training and preparation, teachers must also have supports such as (Futernick, 2010):

1. Adequate time for planning and collaboration

2. A trusting and respectful professional environment

3. Stable, competent, and accountable leadership

4. $\quad$ Reasonable class sizes

5. Adequate access to supplies and quality learning materials

6. Current and reliable data about students' academic achievement

7. Minimal bureaucratic interference

8. Special assistance through programmes like peer-assistance and review when one's performance remains unsatisfactory

In order to upgrade schools, the South African government has allocated eight billion rands over the next three years for the replacement of 496 schools (of which 395 are mud schools), for the supply of water to 1,257 schools, provision of sanitation to 868 schools, and for the connection of another 878 schools to the electricity grid. These investments are in line with the National Development Plan's objective of ensuring that all schools meet the minimum infrastructure standards by 2016 (National Treasury of South Africa, 2013). Teaching effectiveness should be recognized as more than the efforts and attributes of an individual teacher because teachers are only as effective as the systems in which they work. Hence, the State must invest sufficient resources to provide the teachers the facilities, tools, and resources necessary for effective instruction (California Teachers Association, 2007).

\section{CONCLUSION}

In this exploratory study, the high mean scores (85.23 and 74.22) observed for the negative impact of OBE and TBP confirm that these two variables had a very high negative impact on teachers. According to this finding and given the observed strong relationship between OBE and TBP, it can therefore be concluded that in South African schools where the negative impact of OBE is high, it would be typically found that the negative impact of TBP on teachers' job satisfaction would also be high. In dealing with TBP, it is of vital importance that teachers become aware of their fears, identify their ways in which they express fear, recognise the situations that trigger fear and use appropriate strategies to reduce fear and stress in their lives (Barker, 2003). Effective training of teachers needs to take place on a continuous basis to sharpen their professional competencies and address these concerns. Implementing a curriculum without the adequate training of teachers will diminish their chances of achievement and will engender fear regarding the outcomes in education. Further research is required to investigate the causal relationship between the negative impact of curriculum change (such as OBE) on teachers and the impact of TBP on their job satisfaction.

\section{AUTHOR INFORMATION}

Professor Prakash Singh is a professor of education at the Nelson Mandela Metropolitan University in Port Elizabeth, South Africa. He is currently a rated researcher by the National Research Foundation in South Africa, and is a former Senior Research Fulbright scholar. Professor Singh is the author of Innovative Strategies to Develop Better Schools and co-author of Principal Leadership. He has also published widely in peer-reviewed journals, focusing on leadership and management, organisational effectiveness, emotional intelligence, tobephobia, and curriculum development. Professor Singh has presented numerous papers at international conferences. E-mail: Prakash.Singh@nmmu.ac.za

\section{REFERENCES}

1. Alderson, A. \& Martin, M. (2007). Outcomes based education: Where has it come from and where is it going? Issues in Educational Research, 17(2):161-182.

2. Atkinson, J.W. (1957). Motivational determinants of risk taking behaviour. Psychological Review, 64:359372. 
3. Atkinson, J.W. (1964). An introduction to motivation. Princeton: VanNostrand.

4. $\quad$ Balt, D. (2008). Fixing a struggling system. The Teacher, 13(3):26.

5. Barker, P. (2003). Fear. Retrieved from: http://www.beyondintractability.org/essay/fear Accessed 5 April 2008.

6. Berlach, R.G. \& McNaught, K. (2007). Outcomes based education? Rethinking the provision of compulsory education in Western Australia. Issues in Educational Research, 17(1):1-14.

7. Birney, R.C., Burdick, H. \& Teevan, R.C. (1969). Fear of failure. New York: VanNostrand.

8. California Teachers Association. (2007). Promoting teacher quality: Recommendations from the California Teachers Association. Sacramento, CA: California Teachers Association.

9. Chisholm, L. (2000). A South African curriculum for the $21^{\text {st }}$ century. Report of the Review Committee on Curriculum 2005. Pretoria.

10. Clarkson, M. (2004). Quick fixes for Everyday Fears. Toronto: Key Porter Books Limited.

11. Conley, S. \& Glasman, N.S. (2008). Fear, the school organization, and teacher evaluation. Educational Policy, 22(1):63-85.

12. Dawson, T.C. \& Billingsley, K.L. (2000). Unsatisfactory performance: How California's K-12 education system protects mediocrity and how teacher quality can be improved. San Francisco: Pacific Research Institute for Public Policy.

13. Deming, W.E. (1986). Out of the crisis. Cambridge, MA.: MIT Press.

14. Department of Education (DoE) 2009. Report of the Task Team for the review of the implementation of the National Curriculum Statement. Pretoria.

15. Donnelly, K. (2005). Benchmarking Australian primary school curricula. Canberra: Department of Education, Science \& Training. Retrieved from: http://www.dest.gov.au/sectors/school_education/publications_resources/profiles/benchmarking_cui

16. Donnelly, K. (2007). Australia's adoption of outcomes based education: A critique. Issues in Educational Research, 17(2):183-206.

17. Eisner, E.W. (1995). Educational reform and the ecology of schooling. In A.C. Ornstein \& L.S. Behar (Eds.), Contemporary issues in curriculum. Boston: Allyn \& Bacon.

18. Elliot, A.J. \& Thrash, T.M. (2004). The intergenerational transmission of fear of failure. Personality and Social Psychology Bulletin, 30: 957-971.

19. Fullan, M. (2001). Leading in a culture of change. San Francisco: Jossey-Bass.

20. Fullan, M. (2006). The future of educational change: System thinkers in action. Journal of Educational Change, 7: 113-122.

21. Fuhr, D.L. (1993). Managing mediocrity in the classroom: School leaders must rescue students from borderline teachers. The School Administrator, 50(4):26-29.

22. Futernick, K. (2007). A possible dream: Retaining California teachers so all students can learn. Sacramento, CA: California State University.

23. Futernick, K. (2010). Incompetent teachers or dysfunctional systems: Re-framing the debate on teacher quality and accountability. New York: Teachers Network.

24. Gardner, J. \& Bell, A.H. (2005). Phobias and how to overcome them: understanding and beating your fears. New Jersey: New Page Books.

25. Gastorf, J.W. \& Teevan, R.C. (1980). Type A coronary-prone behaviour pattern and fear of failure. Motivation and Emotion, 4(1): 71-76.

26. Ginsberg, R. \& Cooper, B.S. (2008). Introduction. What's fear got to do with it? Educational Policy, 22(1):5-9.

27. Ginsberg, R. \& Lyche, L.F. (2008). The culture of fear and the politics of education. Educational Policy, 22(1):10-27.

28. Grant, N. (2009). Schools of little thought: why change management hasn't worked. Improving Schools, 12(1):19-32.

29. Greenberg, J. \& Baron, R.A. (2000). Behavior in organizations. New Jersey: Prentice Hall.

30. Jones, R. (1997). Showing bad teachers the door. American School Board Journal, 184(11):20-24.

31. Kealey, K.A., Peterson, A.V., Gaul, M.A. \& Dinh, K.T. (2000). Teacher training as a behavior change process: principles and results from a longitudinal study. Health Education \& Behavior, 27(1):64-81.

32. Kyriacou C 1998. Teacher stress: past and present. In J. Dunham \& V. Varma (Eds.), Stress in teachers. London: Whurr. 
33. Lunn, C. (2009). Tobephobia. Port Elizabeth: Nelson Mandela Metropolitan University.

34. Martin, A.J. \& Marsh, H.W. (2003). Fear of failure: Friend or foe? Australian Psychologist, 38(1): 31-38.

35. Masondo, S., Mahlangu, D. \& Mclea, H. (2010). Sacrificed: Millions of young South Africans' futures have been destroyed for an ideological concept - OBE. The Times, 7 July.

36. McClelland, D.C., Atkinson, J.W., Clark, R.W. \& Lowell, E.L. (1953). The achievement motive. New York: Appleton.

37. McGregor, H.A. \& Elliot, A.J. (2005). The shame of failure: Examining the link of fear of failure and shame. Personality and Social Psychology Bulletin, 31: 218 - 231.

38. McMillan, J.H. \& Schumacher, S. (2001). Research in education: a conceptual introduction. New York: Harper.

39. Menuey, B.P. (2005). Teachers' perceptions of professional incompetence and barriers to the dismissal process. Journal of Personnel Evaluation in Education, 18: 309-325.

40. MindTools. (2013). Overcoming fear of failure: Facing fears and moving forward. Retrieved from: http://www.mindtools.com/pages/article/fera-of-failure.htm

41. Mofokeng, S.D. (2004). The implementation of the outcomes-based curriculum 2005 in primary schools in the Reitz district. Unpublished MEd dissertation. Vanderbijlpark: North-West University.

42. National Treasury of South Africa. (2013). Budget 2013: People's guide. Pretoria: South African Revenue Services.

43. Neill, S.B. \& Custis, J. (1978). Staff dismissal: Problems and solutions. Arlington, VA: American Association of School Administrators.

44. Newkirk, T. (2009). Holding on to good ideas in a time of bad ones. Portsmouth, New Hampshire: Heinemann.

45. Ornstein, A.C. \& Hunkins, F.P. (2004). Curriculum: foundations, principles and issues. New York: Pearson.

46. Pfeffer, J. \& Sutton, R.I. (2000). The knowing-doing gap. Retrieved from: http://personnel.ky.gov/NR/rdonlyres/C1C65A3B-65B4-48A1-99CC 9DD68BA78CA0/0/KnowingDoingGapKnowlBrief.pdf

47. Ramkhelawon, J.A. (2010). Tobephobia: A case study. Port Elizabeth: Nelson Mandela Metropolitan University.

48. Robson, C. (2002). Real world research: a resource for social scientists and practitioner-researchers. Oxford: Blackwell.

49. Sanders, W.L. \& Horn, S.P. (1998). Research findings from the Tennessee Value-Added Assessment System. Journal of Personnel Evaluation in Education, 12:247-256.

50. Schargel, F. (2010). 162 keys to school success. New York: Eye on Education.

51. Schargel, F. (2011). America's next educational crisis. Retrieved from: http://www.huffingtonpost.com/franklin-schargel/americas-next-educational_b_883381.html

52. Schoenfeld, A.H. (2006). What doesn't work: The challenge and failure of the What Works Clearinghouse to conduct meaningful reviews of studies of mathematics curricula. Educational Researcher, 35(2):13-21.

53. Singh, P. (2006). Are you suffering from TBP? The Teacher, November.

54. Singh, P. (2007). Research on the effects of Tobephobia on learning outcomes. Paper presented at the Fifteenth World Conference on Cooperative Education. Singapore: 26-29 June 2007.

55. Singh, P. (2008). The effects of Tobephobia on learning outcomes in the educational milieu. International Journal of Learning, 15(3):10-15.

56. Singh, P. (2010). Innovative strategies to develop better schools. Sydney, Australia: Common Ground.

57. Singh, P. (2011). Tobephobia experienced by teachers in secondary schools: An exploratory study focusing on curriculum reform in the Nelson Mandela Metropole. Africa Education Review, 8(2): 372-388.

58. Singh, P. (2013). Accounting enrichment program for gifted high school pupils: Self-regulated learning strategies to develop our future business leaders. International Business and Economics Research Journal, 12(1): 103-112.

59. Singh, P. \& Manser, P.G. (2000). Effects of a shared vision on the attitudes of teachers towards outcomesbased education. South African Journal of Education, 20(2):108-114.

60. Singh, P., Manser, P. \& Dali, C. (2013). Principal leadership: Interconnectedness between emotional intelligence, work-integrated-learning competencies and collegial leaders. Saarbrucken, Germany: LAP Lambert Academic Publishing. 
61. Singh, P. \& Morar, T. (2009). Tobephobia: fear of failure experienced by educators. The International Journal of Knowledge, Culture and Change Management, 9(4): 93-105.

62. Spitzer, D.R. (1977). Achievement motivation and fear of failure in teachers. Paper presented at the Association for Educational Communications and Technology Annual Convention. State University of Albany, New York.

63. Taylor, N. \& Vinjevold, P. (1999). Getting learning right. Report of the President's Education Initiative Project. Johannesburg.

64. Tedrow, M. (2010). Failure is inseparable from the joys of teaching. Teacher Leadership Today. Retrieved from: http://teacherleaders.typepad.com/teacher_leadership_today/2010/01/index.html

65. Tucker, P.D. (1997). Lake Wobegon: Where all teachers are competent. Journal of Personnel Evaluation in Education, 11:103-126.

66. VandenBos, G.R. (ed.) 2007. APA Dictionary of Psychology. Washington, DC: American Psychological Association.

67. Wildemann, V.A.R. (2009). The potential impact of Tobephobia on South African educators. Port Elizabeth: Nelson Mandela Metropolitan University.

68. Wright, A.G.C., Pincus, A.L., Conroy, D.E. \& Elliot, A.J. (2009). The pathoplastic relationship between interpersonal problems and fear of failure. Journal of Personality, 77(4): 997 - 1024.

69. Zimmerman, J. (2006). Why some teachers resist change and what principals can do about it. NASSP Bulletin, 90(3):238-249. 